\title{
Paradoks dystynkcji. Komiks na rynku kultury w Polsce
}

Michał Jutkiewicz 


\section{Dociekania}

\section{Paradoks dystynkcji. Komiks na rynku kultury w Polsce}

Michał Jutkiewicz

TEKSTY DRUGIE 2017, NR 5, S. 88-107

DOI: $10.18318 /$ td.2017.5.6

1.

Wydana w 1979 roku Dystynkcja. Społeczna krytyka władzy sadzenia Pierre'a Bourdieu to klasyczna już pozycja opisująca kulturowe i społeczne sposoby konstruowania gustu. Według francuskiego socjologa podział na kulturę wysoką i niską wynika ze starcia się różnych rodzajów kapitałów oraz dynamicznych procesów, w których wyłaniają się utrwalające status quo habitusy, konstruujące styl życia przedstawicieli różnych klas. W wizji Bourdieu obycie kulturowe staje się kolejnym środkiem, oprócz kapitału ekonomicznego tworząc tytułowe dystynkcje. Książka ta odrzuca obecne w estetyce esencjalistyczne rozumienie smaku na rzecz kulturowej procesualności jego wytwarzania, uwarunkowanego różnymi czynnikami społecznymi'. Dzieło Bourdieu przyczyniło się do zachwiania opozycji między kulturą "niską" i „wysoką", „popularną" lub „elitarną", jednocześnie

Michał Jutkiewicz mgr.W swojej pracy naukowej zajmuje się komiksem, komiksem internetowym, nowymi mediami i narracją transmedialną. Ostatnio opublikował recenzję Miks totalny - OfRemixology. Ethics and Aesthetics after Remix Davida J. Gunkela

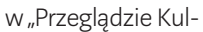
turoznawczym" oraz Konspiracja przeciwko spiskowi w magazynie ha!art. Kontakt: michal.jutkiewicz@ gmail.com

1 P. Bourdieu Dystynkcja. Społeczna krytyka władzy sądzenia, przeł.

P. Biłos, Scholar, Warszawa 2005. 
pokazując, że podziały te są mocno zakorzenione w praktykach kulturowych i instytucjonalnych.

Bourdieu nie pokazuje jednak tylko mechanizmów wytwarzania się gustów klas niższej i wyższej, wyróżnia bowiem jeszcze jedno pole produkcji kulturowej, należące do nowego drobnomieszczaństwa. W środowisku anglosaskim nazywa się tę sferę middlebrow culture, czyli sferę niezbyt wymagającą, której znajomość daje jednak możliwość uprawomocnienia i powiększenia swego kapitału kulturowego w środowiskach drobnomieszczańskich. Dzieła klasyfikowane do tej kategorii nie opierają się na oferowaniu przyjemności najniższych lotów, jednak rzadko są opisywane jako „ambitne” arcydzieła. Francuski socjolog jako tego typu „średnią sztukę" klasyfikuje kino, jazz, powieści detektywistyczne, science fiction i komiks. Inwestycje w te dziedziny produkcji kulturowej dają zaangażowanym w nie osobom poczucie odróżniania się z jednej strony od kultury klasy niższej, z drugiej mogą stać się manifestacją niezgody na estetyczne rozróżnienia tworzone przez wyższą ${ }^{2}$. Dzieła klasyfikowane w ten sposób pozostają nierozpoznane przez środowiska akademickie i, w wyniku tego, nie są włączone w obręb kanonu kultury wysokiej. Te diagnozy z perspektywy czasu wydają się mniej trafne w przypadku takiej dziedziny sztuki jak film, który, jeśli iść za rozumowaniem Bourdieu, w wyniku szerokiego uznania, wyłonienia się dyscypliny filmoznawstwa i wytworzeniu się kapitału szkolnego zorientowanego wokół tej dziedziny humanistyki, został nobilitowany ${ }^{3}$. Kino wciąż jednak nie jest całościowo i esencjalnie uznawane za sztukę wysoką, w przeciwieństwie chociażby do teatru. Autor Dystynkcji zauważa, że we wszystkich wymienionych powyżej dziedzinach produkcji kulturowej istnieje potencjał uprawomocnienia ich poszczególnych przykładów i „wzniesienia” ich w obręb kultury wyższego rzędu. Z drugiej strony następuje proces odwrotny, czyli opisywanie „sztuk średnich" w kategoriach gustu niższego, dyskredytowanie wszelkich produktów należących do tych dziedzin. Są one w takim razie zawieszone między różnymi biegunami, z czego wynika z jednej strony dystynkcja wewnętrzna (podział na ambitne „kino artystyczne” i tzw. blockbustery), z drugiej w przypadku przedstawicieli drobnomieszczaństwa posiadających duży kapitał kulturowy w omawianych dziedzinach - kreowanie przeświadczenia o swojej odmienności i byciu w opozycji do kultury głównego nurtu. Bourdieu opisuje to następująco:

\footnotetext{
2 Tamże, s. 114-115.

3 Tamże, s.90-100.
} 
Na skutek tego, że znaczenie oraz sama wartość dobra kulturowego zależą od systemu dóbr, w który jest ono włączone, powieść detektywistyczna, fantastyka lub komiksy mogą stanowić zgoła prestiżowe, kulturowe właściwości jako przejawy odwagi oraz swobody lub - przeciwnie - zostać zredukowane do swojej zwykłej wartości w zależności od tego, czy powiązane są z odkryciami literackiej czy bądź muzycznej awangardy, czy też nie wychodzą poza własny krąg, tworząc w ten sposób typową konstelację "gustu średniego" i jawiąc się dzięki temu jako to, czym są - czyli jako zwykłe substytuty dóbr prawomocnych. ${ }^{4}$

Celem niniejszego artykułu jest zanalizowanie polskiego rynku komiksowego za pomocą narzędzi, których dostarczył Bourdieu w Dystynkcji. Punktem wyjścia staje się opisywany powyżej stan zawieszenia między kulturą niską i wysoką i wynikające z niego próby legitymizacji komiksu jako pełnoprawnej dziedziny kulturowej oraz budowanie alternatywnej wobec kultury wysokiej tożsamości fana komiksu i idące za nią poczucie posiadania kapitału kulturowego niedostępnego innym. Wydaje się, że takie podejście pozwoli na skonstruowanie mapy umieszczającej komiks w szerszym polu praktyk kulturowych w makroskali oraz zarysowanie wewnętrznych zjawisk i tendencji w obrębie polskiego środowiska komiksowego.

\section{2.}

Źródeł instytucjonalnego przypisania komiksu do kultury niskiej i odebrania mu legitymizacji można dopatrywać się w okresie powojennym. Powiązać to można z ogólnym podejściem do kultury popularnej w latach 40. i 50., wynikającym z popularyzacji myśli szkoły frankfurckiej i sprowadzeniem przez nią „sztuki niskiej” do funkcji politycznej i rozrywkowej przy odarciu jej z wartości estetycznych5 . Bourdieu w Dystynkcji nie zastanawia się nad historycznymi uwarunkowaniami dystynkcji między kulturą niską a wysoką, niemniej jednak podejście reprezentowane przez szkołę frankfurcką odbija dokładnie opisywaną przez niego tendencję do uprawomocniania kultury wysokiej jako intelektualnej, odartej ze sfery afektywnej i nie skierowanej

4 Tamże, s. 115.

5 M. Horkhaimer, T.W. Adorno Dialektyka oświecenia, przeł. M. Łukasiewicz, Wydawnictwo Krytyki Politycznej,Warszawa 2010, s. 123-168. 
na wywoływanie przyjemności ${ }^{6}$. Wzbudzanie emocji utożsamiane jest z niższymi produktami kulturowymi, ich odbiorcy zaś są postrzegani jako naiwni i nieposiadający wystarczającego kapitału kulturowego ${ }^{7}$. Konsekwencją podejścia do kultury masowej reprezentowanego przez Adorno i myślicieli o podobnych poglądach stało się nie tylko dyskredytowanie wytworów „sztuki niskiej", ale również teza o wykorzystywaniu ich w celach politycznych do promowania odpowiednich zdaniem klas wyższych postaw poprzez mechanizmy przemysłu kulturowego.

Mechanizmy te są bardzo łatwe do zaobserwowania w przypadku podejścia do komiksów w Stanach Zjednoczonych. Kulminacją odebrania legitymizacji kulturowej powieściom obrazkowym była opublikowana w 1954 roku praca psychologa Frederica Werthama pod znamiennym tytułem Seduction of the Innocent (uwodzenie niewinnych). Wertham opublikował wyniki swoich badań, w ramach których prowadził wywiady z dziećmi i młodzieżą czytającą komiksy. Wynikać miało z nich, że tego typu lektura wywołuje u odbiorców niezdrowe zachowania społeczne, czyni ich podatnymi na agresję, promując zachowania dewiacyjne. Zdaniem Werthama powieści obrazkowe promowały analfabetyzm, odciągając dzieci od konsumowania wartościowych dzieł kulturowych ${ }^{8}$. Seduction of the Innocent nie było skierowane przeciw konkretnym dziełom komiksowym, ale przeciwko całej dziedzinie sztuki, jako aksjomat przyjmując jej niższość i schlebianie gustom klas, o których rozwój powinny dbać instytucje kulturowe. Wertham w tym kontekście jest idealnym przedstawicielem klasy wyższej, wspartym przez swój kapitał kulturowy i dysponującym zapleczem instytucjonalnym. Amerykański psycholog próbował w pełni wykorzystać dostępne mu środki społeczne i ruszył na krucjatę, której celem było zdyskredytowanie komiksu. Udzielał licznych wywiadów w radiu i telewizji, o jego badaniach zaczęto pisać artykuły w gazetach i magazynach. Gdy do dyskusji włączyły się instytucje państwowe, Wertham wystąpił przed specjalnie powołaną do tego, by zbadać tę sprawę, komisją w kongresie USA. W wyniku tych działań i nacisków ze strony instytucji politycznych i kulturowych, firmy wydawnicze zajmujące się publikowaniem powieści obraz-

6 P. Bourdieu Dystynkcja..., s. 83-126.

7 Tamże, s. 83-86.

8 F. Wertham Seduction of the Innocent, Main Road Books, Delhi 2004.

9 D. Hajdu The ten-cent plague. The great comic-book scare and how it changed America, Picador, New York 2009 
kowych przyjęły zasady autocenzury nazwane „kodeksem komiksowym”10. Głosił on m.in., że w komiksach nie będzie ukazywanej nagości czy nie będzie się gloryfikować zachowań niemoralnych".

Publikacja Seduction of the Innocent miała bardzo duży wpływ na komiks, jego postrzeganie i rozwój nie tylko w Stanach Zjednoczonych. Recepcja badań Werthama w krajach bloku wschodniego była najprawdopodobniej znikoma, niemniej jednak wiele zarzutów podnoszonych wobec sztuki komiksowej w okresie stalinizmu, a nawet później w Związku Radzieckim ${ }^{12}$ i Polsce wydaje się zbieżne z poglądami Amerykanina. Pojawiały się głosy na temat propagowanego wśród zachodniej młodzieży za pomocą powieści obrazkowych zepsucia i analfabetyzmu ${ }^{13}$, a przykład takiego myślenia można znaleźć chociażby w Poetyce Kulawika, który pisał:

[Komiks] odegrał początkowo dużą rolę kulturową: przeznaczony był dla analfabetów i półanalfabetów, obcokrajowców szukających w Stanach Zjednoczonych zarobku. Jako taki był specyficznym elementarzem, później jednak upowszechnił się, znalazł odbiorcę dziecięcego i młodzieżowego i jest dzisiaj smutnym fenomenem kultury. ${ }^{14}$

Podejście, które obniżało wartość sztuki komiksowej na rynku kultury, opierało się głównie na założeniu, że jest to sztuka nie tyle klas średnich, lecz której odbiorcami jest młodzież, u której może prowadzić do rozwijania szkodliwych nawyków ${ }^{15}$. Podobnie jak w Stanach Zjednoczonych, reakcją na takie podejście było wytworzenie instytucjonalnych mechanizmów, których zadaniem było regulowanie umieszczanych w sztuce komiksowej treści. O ile kodeks komiksowy w USA był sposobem regulacji wewnętrznej, w przypadku

10 Tamże. s.305-318.

11 Comic book code of 1954, https://en.wikisource.org/wiki/Comic_book_code_of_1954 (lipiec 2017).

J. Alaniz Komiks. Comic Art in Russia, University Press of Mississippi, Mississippi 2010.

Por. K. Skrzypczyk Komiksologia, czyli komiks w ujęciu teoretyczno-badawczym - w perspektywie Sympozjów Komiksologicznych, w: KOntekstowy MIKS. Przez opowieści graficzne do analiz kultury współczesnej, red. G. Gajewska, R. Wójcik, Wydawnictwo Poznańskiego Towarzystwa Przyjaciół Nauk, Poznań 2011, s. 355. ników przed literaturq̨ szkodliwą, "Przegląd Biblioteczny" 1953, s. 226. 
krajów bloku wschodniego rolę tę przejęły istniejące instytucje cenzorskie. Od lat 6o. zaczęto w Polsce wydawać komiksy, jednak ich treść ograniczona została do realizowania politycznych i pedagogicznych postulatów państwa, które to zjawisko analizuje Paweł Timofiejuk w artykule Polski komiks jako narzędzie propagandy. Ukazuje on historię sztuki komiksowej jako na różne sposoby i w różnym stopniu uwikłanej w funkcje perswazyjne ${ }^{16}$. Najważniejsze z punktu widzenia tego artykuły jest, znajdujące się w ostatniej części tekstu spostrzeżenie Timofiejuka, że instytucjonalne traktowanie powieści obrazkowych jako spełniających postulaty polityczne nie skończyło się wraz ze zmianą ustrojową ${ }^{17}$. Zmiana zasad funkcjonowania rynku ekonomicznego i rynku kulturowego sprawiła, że wyłoniły się różne rodzaje komiksów propagandowych. Jednym z najbardziej widocznych i charakterystycznych jest ten, który ma realizować określoną politykę historyczną. Instytucje państwowe takie jak ministerstwa lub muzea, funkcjonujące w tradycyjnym przekonaniu o młodzieżowym odbiorcy sztuki komiksowej, finansują ich publikację. Timofiejuk zauważa, że zjawisko to jest tak odrębne od reszty produkcji dzieł komiksowych w Polsce, że należy mówić o specyficznym, oddzielnym nurcie $^{18}$.

Jako mechanizm działania rynku kulturowego odnosi się to jednak do całości omawianej dziedziny sztuki, w sposób instytucjonalny ugruntowując jej pozycję jako czegoś z obrębu kultury niższej, mającego charakter funkcjonalny, więc niedysponującego identycznym mandatem jak dzieła z zakresu kultury wysokiej. Bourdieu w Dystynkcji ukazuje, jak takie zabiegi stwarzają podział klasowy i tworzą odrębne, izolowane instytucjonalnie habitusy ${ }^{19}$. W tym przypadku sztuka komiksowa staje się więc domeną młodzieżową, a jej odbiorcy traktowani są jako nieposiadający jeszcze odpowiedniego kapitału kulturowego, który należy dopiero konstruować przekazem, a jego wartość artystyczna schodzi na dalszy plan. Timofiejuk, jako przedstawiciel środowiska komiksowego, przyznaje w swoim tekście, że dzieła publikowane w nurcie komiksu realizującego politykę historyczną mają znikomą wartość ze względu na swoją "słabą jakość graficzną i narracyjną"20. Jednocześnie

\footnotetext{
16 P. Timofiejuk Polski komiks jako narzędzie propagandy, w: KOntekstowy MIKS, s. 179-197.

17 Tamże. s. 192.

18 Tamże.s. 194.

19 P. Borudieu Dystynkcja..., s. 215-260.

P. Timofiejuk Polski komiks jako narzędzie propagandy, s. 193.
} 
w ostatnich akapitach Polskiego komiksu jako narzędzia propagandy autor czuje potrzebę obrony sztuki komiksowej, podkreślając, że dzieła komiksowe są "dojrzałą i uniwersalną dziedziną sztuki"21. Zdanie to byłoby niepotrzebne, gdyby tekst ten opisywał literaturę czy sztuki plastyczne, jednak w przypadku powieści obrazkowych Timofiejuk czuje potrzebę obrony komiksu przed opisywanym w całym artykule sprowadzeniem go do funkcji propagandowej, i, co za tym idzie, obniżaniem jego wartości na rynku kulturowym. Zakończenie tekstu to próba legitymizacji tej dziedziny produkcji kulturowej wobec opisywanych wcześniej tendencji. Artykuł Polski komiks jako narzędzie propagan$d y$ w swoich finałowych zdaniach staje się egzemplifikacją napięcia między instytucjonalnymi próbami umiejscowienia powieści obrazkowych w polu kultury niższej a jego obroną przed tymi samymi mechanizmami. Timofiejuk, jako właściciel wydawnictwa komiksowego (Timof Comics) i przedstawiciel środowiska fanów komiksu (wieloletni prezes Polskiego Stowarzyszenia Komiksowego), przeciwstawia się opisywanym przez siebie sposobom deprecjacji sztuki komiksowej.

Napięcie między instytucjonalnym patrzeniem na komiks a środowiskowymi próbami jego legitymizacji uobecniły się w roku 2010, kiedy to Ambasada Polska w Berlinie wraz z Ministerstwem Spraw Zagranicznych postanowiły opublikować antologię komiksów celebrujących obchody Roku Chopinowskiego. Chopin New Romantic ${ }^{22}$ wpisuje się w problematyzowane powyżej sposoby traktowania sztuki komiksowej przez instytucje. Miało być to wydawnictwo skierowane do młodzieży, w sposób dla niej atrakcyjny promujące twórczość polskiego kompozytora. Jego celem miała być zachęta dla młodych do powiększenia swego kapitału kulturowego i zapoznania się z twórczością Chopina, uzyskana za pomocą dzieła znajdującego się niżej w hierarchii kulturowej. Okazało się jednak, że w jednym z utworów pojawiły się przekleństwa łamiące projektowane decorum. Informacją o tym zainteresowały się media i opisały to $\mathrm{w}$ atmosferze skandalu ${ }^{23}$. Publikacji zarzucono wulgaryzację i wypaczenie „polskiego posłannictwa kulturowego"24. Ministerstwo postanowiło zniszczyć cały nakład antologii, co wywołało

21 Tamże, s. 195.

Chopin New Romantic, Kultura Gniewu, Warszawa 2010.

C. Jopek Ch..., k... i "cweloholokaust”. Tak MSZ promuje Chopina, "TVNWarszawa” 21.02.2011, http://tvnwarszawa.tvn24.pl/informacje,news, ch-k-i-cweloholokaust-tak-msz-promujechopina,26448.html (lipiec 2017). 
protesty środowiska fanów i twórców. Tocząca się wokół sprawy dyskusja zaczęła poruszać problem legitymizacji sztuki komiksowej i jej funkcjonowania w obrębie rynku kultury. „W Polsce pokutuje przekonanie, że komiks to książka dla analfabetów, że jest bezwartościowy", stwierdza w wywiadzie Krzysztof Ostrowski, autor kontrowersyjnej części Chopin New Romantic ${ }^{25}$, bezpośrednio odnosząc się do opisanych wyżej utrwalonych mechanizmów obniżania wartości sztuki komiksowej. Taki przykład myślenia o powieściach obrazkowych był również wyśmiewany na fanpage'u Ochronić nakład „Chopin New Romantic" na portalu Facebook, który stał się centrum koordynującym protesty w sprawie zniszczenia publikacji. ${ }^{26}$ Założyciele strony, jak i osoby zaangażowane $\mathrm{w}$ protesty, umieszczały na nim treści ukazujące stereotypy, jakimi ich zdaniem kierują się instytucje w swoim podejściu do komiksów, by skonfrontować je z faktem, że jest to pełnoprawny obszar produkcji kulturowej ${ }^{27}$.

Kontrowersje wokół antologii sponsorowanej przez Ministerstwo Spraw Zagranicznych stanowią dobry przykład mechanizmu walki o uprawomocnienie sztuki komiksowej. Chopin New Romantic dobrze realizuje spostrzeżenie Bourdieu, że sztuki średnie zostają zauważone w momencie, gdy wzbudzają kontrowersje i stają w opozycji do funkcjonujących standardów kulturo$w_{\text {wch }}{ }^{28}$. Jednocześnie, kontrowersje te spełniały rolę tożsamościową - protesty wokół komiksu sprawiły, że wyłoniła się widoczna społecznie grupa, skonsolidowana przeciwko zawężonemu rozumieniu kultury jako tylko jej elementów z pola sztuk wysokich. „Ta afera skłania mnie do smutnej refleksji. Widać jak mocno siedzi w Polakach przekonanie, że kultura to tylko to, co zaszczepiono nam w szkole"29 - stwierdza Szymon Holcman, krytykując mechanizmy uzyskiwania kapitału kulturowego. W tym samym wywiadzie stwierdza on, że komiks Ostrowskiego był subwersywny i krytyczny wobec

25 B.T. Wieliński Nie mielcie Chopina, "Gazeta Wyborcza" 24.02.2011, wyborcza. pl/1,75410,9156086,Nie_mielcie_Chopina.html (lipiec 2017).

26 "Ochronić Nakład Chopin New Romantic", https://www.facebook.com/OchronicNakladChopinNewRomantic/ (lipiec 2017).

27 Tamże. https://www.facebook.com/OchronicNakladChopinNewRomantic/photos/rpp.193030 194052038/193265104028547/?type=3\&theater $($ lipiec 2017).

29 G. Antoniewicz Komiks "Chopin New Romantic" - polityka i fani, „Dziennik Bałtycki" 27.02.2011, www.dziennikbaltycki.pl/artykul/374092,komiks-chopin-new-romantic-polityka-i-fani,id. html (lipiec 2017). 
współczesnej kultury ${ }^{30}$. Ruch społeczny skoncentrowany na ocaleniu Chopin New Romantic działał na zasadach opozycji wobec obecnych w kulturze sposobów uprawomocnienia i dystynkcji, jednocześnie zgłaszając akces komiksu do sztuki wyższej.

Wydarzenia związane z wydaniem antologii zakończyły się decyzją MSZ, że publikacja nie zostanie zniszczona, a będzie promowana dla nowego grona odbiorców, którym są „zainteresowane środowiska twórcze i artystyczne, zwłaszcza reprezentatywne dla tego środowiska ekspresji twórczej jakim jest sztuka komiksu" ${ }^{\text {"1 }}$. Tym samym środowisko fanów zostało instytucjonalnie uznane jako samodzielna grupa społeczna, ze swym własnym habitusem i systemem dystrybucji kapitału. Chopin New Romantic trafiło na ten wąski rynek kulturowy z jego własnymi mechanizmami dystrybucji, takimi jak obieg kolekcjonerski. Jednocześnie jednak gest ten systemowo potwierdza dystynkcję odbiorców komiksów od całości pola produkcji kulturowej, a rozpoznanie i uprawomocnienie sztuki komiksowej izoluje ją od reszty sztuk. Gdy więc na stronie Ochronić naktad "Chopin New Romantic" autorzy ogłaszają zwycięstwo ${ }^{32}$, jest to sukces nie kontrkulturowych i subwersywnych aspektów konfliktu, a ich wymiaru tożsamościowego, wyłonienia się konkretnie zdefiniowanych "nas" mających społeczną moc sprawczą.

\section{3.}

Krystalizacja społeczności fanów komiksów nie rozpoczęła się, oczywiście, w 2010 roku. Fandom ten zaczął się kształtować w latach8o., u swoich początków związany będąc z powstającym w tym samym okresie środowiskiem miłośników fantastyki skupionych wokół czasopisma „Fantastyka”. Już wtedy jednak pojawiły się na łamach magazynu wątpliwości, czy powieści obrazkowe i artykuły o nich mają w nim miejsce, jako że są to sztuki odrębne i niezależne od głównej tematyki czasopisma ${ }^{33}$. W końcu jednak zdecydowano, że

30 Tamże.

31 Informacja dotyczq̨ca komiksu "Chopin New Romantic”, „Wiadomości MSZ" 2.03.2011, msz.gov. $\mathrm{pl} / \mathrm{pl} /$ aktualności/wiadomości/aktualność_41574. w: Confessions of an aca-fan. The official weblog of Henry lenkins 29.11.2013, http://henryjenkins. org/blog/2013/11/participatory-poland-part-four-notes-on-comics-fandom-in-poland.html (lipiec 2017). 
sztukę komiksową można promować na łamach „Fantastyki” i to tam pojawiły się pierwsze odcinki Funky Koval, najważniejszej polskiej powieści obrazkowej z tego okresu ${ }^{34}$. Mechanizmy odróżniające pola produkcji kulturowej były silne i środowisko fanów komiksów dążyło do emancypacji, w wyniku której z czasem wyłoniło się nowe czasopismo, „Fantastyka - Komiks”, na łamach którego omawiano już zagadnienia stricte związane z tą tematyką: publikowano tam twórczość artystów polskich i zagranicznych, opisywano wydarzenia ze świata, budowano podstawy instytucjonalnej krytyki sztuki komiksowej, jak i przybliżano osiągnięcia zachodnich (głównie frankofońskich) badań naukowych zajmujących się komiksem.

Ten ostatni aspekt działalności czasopisma jest istotny ze względu na procesy legitymizujące komiks. Jak zauważa Bourdieu, bardzo ważnym elementem budowania kapitału kulturowego jest uwikłanie go w kapitał szkol$n y^{35}$. To dyskurs akademicki jest głównym czynnikiem określającym zarówno kanoniczność sztuk i dzieł z nich się wyłaniających, jak i ich przynależność do sfery wyższej ${ }^{36}$. Badaniami komiksu zaczęto zajmować się na zachodzie w latach 70., stopniowo odchodząc od paradygmatów zarysowanych przez szkołę frankfurcką ${ }^{37}$. Naukowe podejście do tej sztuki ma również polskie tradycje ${ }^{38}$, chociaż znajdowało się ono zazwyczaj na marginesie działalności akademickiej. Bardzo często refleksjom nad definicją i charakterem komiksu towarzyszyły rozważania na temat wartości sztuki komiksowej i jej roli w kulturze, czego przykładem może być książka Krzysztofa Teodora Toeplitza Sztuka komiksu. Próba definicji nowego gatunku artystycznego ${ }^{39}$.

W 2001 roku pojawiła się inicjatywa organizowania wraz z Międzynarodowym Festiwalem Komiksów w Łodzi Sympozów Komiksologicznych -

34

M. Parowski, J. Rodek, B. Polch Funky Koval, „Komiks - Fantastyka” 1987 nr 1.

P. Bourdieu Dystynkcja..., s. 32-40.

Tamże, s. 90-100.

Por. K. Skrzypyczk Komiksologia, czyli komiks w ujęciu teoretyczno-badawczym, s. 347 oraz: J. Szyłak Poetyka komiksu. Warstwa ikoniczna i językowa, Wydawnictwo Słowo, Obraz, Terytoria, Gdańsk 2000, s. 5-11 i również: M. Jutkiewicz O rozumieniu komiksów, czyli przygody małego Nemo w krainie (meta)narratologii, "Tekstualia. Palimpsesty Literackie Artystyczne Naukowe” $2015 \mathrm{nr} 4$ (43), s. 39-43.

R.K. Przybylski Słowo i obraz w komiksie, w: Pogranicza i korespondencje sztuk, red. T. Cieślikowska, J. Sławiński, Zakład Narodowy im. Ossolińskich, Wrocław 1980 oraz: K.T. Toeplitz Sztuka komiksu. Próba definicji nowego gatunku artystycznego, Czytelnik,Warszawa 1985.

K.T. Toeplitz Sztuka komiksu. 
wydarzeń naukowych i popularnonaukowych naśladujących formułą konferencje. Spotkania te pozwoliły stworzyć na tyle odrębny głos w obrębie środowiska komiksowego, że cały nurt rysujący się wokół corocznych spotkań został nazwany przez Jerzego Szyłaka „łódzką komiksologią”. Jej głównym działaczem i przedstawicielem został Krzysztof Skrzypczyk. Szyłak, sam będący badaczem, krytykiem i twórcą scenariuszy komiksowych i postacią silnie związaną ze środowiskiem fanów komiksu od jej początków, postanowił napisać w 2013 roku książkę Komiks w szponach miernoty, która m.in. krytycznie odnosiła się do tej części fandomu komiksów. Głównym zarzutem badacza był brak odpowiedniego zaplecza akademickiego biorących udział w Sympozjach. Szyłak pisze wręcz o parodiowaniu nauki ${ }^{40}$. Celem niniejszego artykułu nie jest określanie stopnia akademickości i rzetelności badawczej Skrzypczyka i innych przedstawicieli łódzkiej komiksologii, a ten aspekt Komiksu w szponach miernoty zostaje tu celowo pominięty. Niemniej jednak projekt powołania do życia komiksologii jest spójną i systemową propozycją, której główną funkcją ma być budowanie kapitału szkolnego i kulturowego sztuki komiksowej, dzięki czemu będzie ona traktowana jako równoprawne pole produkcji kulturowej. Jest to próba walki o legitymizację. W tej części tekstu proponuję przyjrzeć się myśli Krzysztofa Skrzypczyka z tej perspektywy, zestawiając ją z krytyką Szyłaka zamieszczoną w Komiksie w szponach miernoty jako alternatywną propozycją działania na rzecz uprawomocnienia.

Skrzypczyk i Szyłak wychodzą od podobnych założeń. Stwierdzają, że redystrybucja kapitału akademickiego i zwiększenie roli badania komiksu w jego obrębie są konieczne dla traktowania sztuki komiksowej jako równoprawnej dziedziny kulturowej"1. Różnią się jednak w podejściu do sposobów uzyskiwania tego kapitału. W jednym z przypisów do tekstu Komiksologia, czyli komiks w ujęciu teoretyczno-badawczym - w perspektywie Sympozjów Komiksologicznych, Krzystof Skrypczyk potanowił zamieścić coś na kształt manifestu programowego, w którym pisze:

Uważam, że analityczno-badawcze zajmowanie się komiksem przez reprezentantów różnych dyscyplin nauki nie gwarantuje ujmowania komiksu jako AUTONOMICZNEGO obiektu badań naukowych [...] i tym samym - nie gwarantuje pełnej emancypacji komiksu jako odrębnego gatunku artystycznego. Chodzi o to, by komiks nie był traktowany jako

\footnotetext{
40 J. Szyłak Komiks w szponach miernoty, Timof Comics, Warszawa 2013, s. 53-55. 
gatunek „gorszy” wobec tych gatunków, które stanowią „właściwy” przedmiot badań dla reprezentantów poszczególnych dyscyplin naukowych. [...] A to właśnie idea komiksologii stwarza i uprawomocnia ramy teoretyczne i metodologiczne takiej „stricte komiksowej” płaszczyzny badawczej [...]. Bo celem nadrzędnym emancypacji sfery badań nad komiksem jest doprowadzenie do sytuacji, w której autonomizacja (a więc też i nobilitacja) komiksu jako osobnego gatunku artystycznego nie będzie kwestionowalna. ${ }^{42}$

Podstawowym wyznacznikiem wartości w tym ujęciu staje się więc samodzielność sztuki komiksowej. Autonomia związana według Skrzypczyka jest z izolacją danej sztuki z pola kulturowego. Takie oddzielenie jest jego zdaniem sposobem na budowanie własnego systemu wartości, własnych mechanizmów uzyskiwania kapitału, który byłby uniezależniony od wszelkich innych mechanizmów kulturowych. Zdobywanie przez komiksologów kapitału kulturowego i rozpoznanie na uniwersytetach ma sens tylko jako narzędzie pozwalające na uniezależnienie się sztuki komiksowej. Gwarantem takiego stanu rzeczy ma być rozwijanie komiksologii jako odrębnej dziedziny naukowej, z jej własnymi narzędziami i metodologiami. Skrzypczyk powołuje się na teatrologię, muzykologię i filmoznawstwo nobilitujące artystycznie przedmiot swoich badań poprzez wyizolowanie go z pola badawczego innych dyscyplin ${ }^{43}$. Jednocześnie krytykuje literaturoznawstwo, narratologię i historię sztuki jako dziedziny badawcze, które rozmywają swoje granice i, zajmując się komiksem, traktują tę sztukę jako coś gorszego ${ }^{44}$. Skrzypczyk staje po stronie nauki czystej i opartej na widocznych podziałach i granicach, odrzucając wszelkie formy badań interdyscyplinarnych czy transdyscyplinarnych ${ }^{45}$. Oznacza to również odrzucenie całej tradycji badania komiksu w Polsce, jako przygodnej i marginalnej. Komiksologię, według Skrzypczyka, trzeba budować w Polsce od podstaw, w sposób programowy.

42 K. Skrzypczyk Komiksologia..., s. 351.

43 Tamże, s. 352.

Tamże, s. 353 .

K. Skrzypczyk Wprowadzenie. (O komiksologii - na pograniczu rozumienia i nieporozumienia), w: Komiks a komiksologia. Ku rozpoznaniu i charakterystyce wzajemnych relacji między gatunkiem a jego teoriq. Antologia referatów 10. Sympozjum Komiksologicznego, red. K. Skrzypczyk, Stowarzyszenie Twórców "Contur", Łódź 2010, s. 13. 
Jednocześnie główny działacz Sympozjów Komiksologicznych podkreśla, że jest to tylko środek do osiągnięcia celu, jakim jest pełna legitymizacja i włączenie w obręb sztuk wyższych. Pisze, że by dotrzeć do „opiniotwórczych elit kulturowych [...] zakładamy konieczność posługiwania się «ich językiem»"46. Jak zauważa Jerzy Szyłak, buduje to opozycję między „nami” a "nimi” ${ }^{\prime 4}$. Środowisko czytających komiksy i zaangażowanych w ich naukowy opis musi w oczach Skrzypczyka wkupić się w łaski środowisk akademickich, naśladując ich zasady. Jednocześnie jest on jednak nastawiony wobec nich negatywnie, uznając je za klasę, która prześladuje sztukę komiksową, odbierając jej miejsce wśród elitarnego kanonu obszarów produkcji kulturowej. Dlatego też wszelkie inicjatywy mające na celu naukową refleksję nad powieściami obrazkowymi muszą pochodzić z samego środowiska. Każda refleksja zewnętrzna będzie skażona myśleniem o komiksie jako o czymś gorszym $^{48}$.

Interesujące jest to, jak bardzo diagnozy Skrzypczyka na temat funkcjonowania elit i wynikającego z ich inicjatyw redystrybucji kapitału pokrywają się z diagnozami Bourdieu. Jego sceptycyzm wobec uniwersytetów i innych instytucji ma charakter kontrkulturowy i podobny jest do tego, opisywanego w przypadku kontrowersji wokół Chopin New Romantic. Podobnie jak organizatorzy protestów przeciwko zniszczeniu wydanej przez MSZ antologii, stawia on na moc społecznego działania. Uprawomocnienie komiksu wiąże się z wykreowaniem silnego środowiska. Aby to jednak osiągnąć, konieczna jest izolacja - wykształcenie się silnej grupy społecznej, która korzysta z dostępnych mechanizmów dystrybucji kapitału w sposób świadomy, a zarazem bez ich akceptacji, zachowując odrębny i elitarny charakter habitusu fanów sztuki komiksowej.

Jerzy Szyłak krytykuje Skrzypczyka za właśnie takie myślenie. Jego zdaniem podział na środowisko fanów i elity zasługuje na ośmieszenie ${ }^{49}$. Wielokrotnie na łamach Komiksu w szponach miernoty podkreśla tradycję refleksji akademickiej nad komiksem - na świecie i w Polsce - pokazując jej istotną

46 K. Skrzypczyk Sympozjum Komiksologicznego. Eksplikacja, w: Komiks jako zjawisko artystyczne - na pograniczu sztuk, mediów gatunków. Antologia referatów 8. Sympozjum Komiksologicznego, red. K. Skrzypczyk, Stowarzyszenie Twórców "Contur", Łódź 2008, s. 90.

47 J. Szyłak Komiks w szponach miernoty, s. 67.

48 K. Skrzypczyk Komiksologia..., s. 353.

49 J. Szyłak Komiks w szponach miernoty, s. 67-69. 
rolę $e^{50}$. Książka ta to wezwanie do zachowania rzetelności naukowej wraz z jej wszelkimi zasadami, czyli przejęcia wszelkich zasad funkcjonowania w środowisku akademickim, wraz z zachowaniem jego dyskursu. Szyłak nie widzi sensu w postulatach o bronieniu wartości sztuki komiksowej, gdyż jej nobilitacja jego zdaniem już się dokonała, chociaż tylko w przypadku konkretnych dzieł komiksowych..$^{51}$ Autor Komiksu w szponach miernoty ucieka od esencjalistycznego traktowania sztuki komiksowej jako czegoś, co miałoby wewnętrzną wartość. Przyznaje, że wiele dzieł powstaje w obrębie kultury popularnej i spełnia jej zapotrzebowania rynkowe ${ }^{52}$. Jednocześnie dostrzega potencjał samego medium i stwierdza, że mechanizmy uznania zależą od konkretnych realizacji. Stawia zatem na pluralizm, który pozwala na wyróżnienie się komiksów posiadających wartości artystyczne ${ }^{53}$. Ich pozycja zależy głównie od uznania odbiorców ${ }^{54}$.

Źródłem stosunku polskiego społeczeństwa do sztuki komiksowej jest, według Szyłaka, jej marginalność. Z tą diagnozą zgadza się Skrzypczyk, jednak jego projekt zakłada zmianę stanu rzeczy. Komiks ma być w oczach komiksologów sztuką nie umasowioną, ale o większym zasięgu społecznym ${ }^{55}$. Szyłak natomiast, sceptyczny wobec prób zmiany systemu kulturowego, uznaje marginalność komiksu jako coś, co należy zaakceptować. Odrzuca więc komiksologiczną krytykę mechanizmów redystrybucji kapitału kulturowego i nie sprzeciwia się wynikającym z nich dystynkcjom kulturowym. Co za tym idzie, zgadza się na nieokreślone umiejscowienie między sferą niską a wysoką, podkreślając potencjał sztuki komiksowej do posiadania wartości artystycznych i uprawomocnienia jej konkretnych dzieł w polu produkcji kulturowej ${ }^{56}$.

\section{4.}

Opisane powyżej podejścia swoją aksjologię czerpią z różnego stosunku wobec autonomii sztuki komiksowej i wynikającej z niej autonomii środowiska

\footnotetext{
50 Tamże, s. 96-109.

51 Tamże, s. 131-133.

52 Tamże, s. 115.

53 Tamże, s. 133.

54 Tamże.

55 K. Skrzypczyk Komiksologia.., s. 363.

56 J. Szyłak Komiks w szponach miernoty, s. 115-116.
} 
fanów. Postulaty Skrzypczyka wiążą się z wykorzystaniem fandomu, pojmowanego jako ustabilizowany i zwarty ruch. Szyłak postrzega zrzeszenie fanowskie jako dynamiczną siłę o wewnętrznych mechanizmach dystynkcji i sposobach dystrybucji kapitału co pokrywa się z diagnozami Johna Fiska w jego kanonicznym tekście Kulturowa ekonomia fandomu ${ }^{57}$, środowisko otwarte na nowe zjawiska zachodzące w jego obrębie $e^{58}$. Takie wyjście z izolacji jest postrzegane jako sposób na poszerzenie grona odbiorców komiksu, co zwiększa zasięg rynku, przekładając się na wzrost zysków ekonomicznych. Oznacza to jednak zbliżenie się do innych sztuk, naśladowanie innych rynków, co przekreśla postulat autonomiczności.

Takie Wyjście z getta postulowane jest przez Sebastiana Frąckiewicza ${ }^{59}$. W książce noszącej ten tytuł przeprowadza on wywiady z różnymi przedstawicielami środowiska komiksowego, w których proponuje współpracę ze światem sztuki i wystawianie komiksów w galeriach. Zabiegi te mają w Polsce długą tradycję, jako że festiwalom regularnie towarzyszą wystawy prac komiksowych różnych artystów, a muzea i galerie umieszczają w swoich przestrzeniach przykłady sztuki komiksowej ${ }^{60}$. Frąckiewicz zauważa jednak, że wciąż są to wydarzenia organizowane przez miłośników powieści obrazkowych dla nich samych i nie idzie za tym współpraca między fandomem a grupą społeczną, którą nazywa art worldem. Grupa ta jest elitarna i zajmuje się już nobilitowanymi dziedzinami sztuki, tak więc w walce $\mathrm{z}$ „niskim statusem" sztuki komiksowej" należy skoncentrować się na tworzeniu wystaw, które byłyby wynikiem zazębiania się dwóch grup społecznych. Zdaniem Frąckiewicza następstwem byłby wzrost wartości kulturowej powieści obrazkowych, ale też wykorzystanie zaplecza ekonomicznego, w które uwikłani są fani. Autor Wyjścia z getta w wielu miejscach wspomina o tym, że dostęp do tego pola produkcji kulturowej wiąże się z możliwościami wykorzystania całego systemu „grantów, stypendiów artystycznych, nagród i obiegu

57 Por. J. Fiske Kulturowa ekonomia fandomu, przeł. M. Filiciak, „Kultura Popularna” 2008 nr 3 (21), S. 17-29.

58 Por. J. Szyłak Komiks w szponach miernoty, s. 173-175. S. Frąckiewicz Wyjście z getta. Rozmowy o kulturze komiksowej w Polsce, 40000 Malarzy, Warszawa 2012.

60 Niezależne wystawy i galerie komiksowe, http://www.komiks.gildia.pl/imprezy/niezalezne-wystawy-i-galerie (lipiec 2017).

61 S. Frąckiewicz Nieufność i uprzedzenia, „Arteon” 2011 nr 11, s. 18. 
galeryjnego"62. Ma on świadomość, że zyskiwanie kapitału kulturowego jest silnie powiązane ze wzrostem kapitału ekonomicznego ${ }^{63}$.

Postulaty Frąckiewicza związane są ze zmianą sposobu definiowania sztuki komiksowej i odejściem od jej tradycyjnej formy publikacji książkowej. W swoich wywodach czerpie on bardzo mocno z tego, co postuluje Jakub Woynarowski, który jest twórcą, promotorem i praktykiem formy, jaką nazwał story art $^{64}$. Nurt ten ma oznaczać awangardowe przykłady produkcji komiksowej lub komiksopodobej, które jednak powstają w obrębie art worl$d u$. Dzieła te odznaczają się tym, że są przeznaczone do wystawiania w galeriach i charakteryzują się intelektualnym dystansem typowym dla sztuk wyższych.

Szyłak poświęca drugą część Komiksu w szponach miernoty krytyce założeń Woynarowskiego, pokazując, że zastosowane przez niego dystynkcje z powodu braków definicyjnych służą tylko izolacji sztuki komiksowej od wymiaru artystycznego ${ }^{65}$. Badacz podkreśla, że autor terminu story art używa go do tego, żeby uprawomocnić swoją twórczość w obrębie środowiska artystów, a nie po to by nobilitować komiks ${ }^{66}$. Przy okazji krytykuje również Frąckiewicza, ukazując, że postulowane przez autora Wyjścia z getta zmiany oznaczają tak daleko idące ingerencje w utrwalony kształt sztuki komiksowej, że grożą one zatraceniem jej esencjalnych cech ${ }^{67}$.W tym przypadku odejście od autonomii powieści obrazkowych wiąże się z przełamaniem ich dystynkcji wobec sztuk wizualnych.

\section{5 .}

Szyłak w Komiksie w szponach miernoty sprzeciwia się zjawisku zacierania różnic między komiksem a sztuką wystawianą w galeriach, jednocześnie jednak kilkukrotnie podkreśla zbieżność powieści obrazkowych z inną dziedziną

\footnotetext{
62 Tamże.

63 S. Frąckiewicz Komiks Bękartem Kultury-prawie podsumowanie, http://podchmurka.blogspot. com/2011/07/komiks-bekratem-kultury-prawie.html (lipiec 2017).

64 J. Woynarowski W stronę formy otwartej. Polski komiks w przestrzeni intermediów, "Zeszyty Komiksowe" $2010 \mathrm{nr} 10$, s. 8-11.

65 J. Szyłak Komiks w szponach miernoty, s. 167-256.

66 Tamże, s. 249-254.

67 Tamże, s. 313-314.
} 
produkcji kulturowej, jaką jest literatura. Zaznacza, że nie oznacza to zatracenia cech formalnych medium komiksowego, a jedynie to, że jego rozwój i sposób funkcjonowania zbieżny jest z rozwojem literatury w większym stopniu niż z innymi sztukami ${ }^{68}$.

Wykorzystywanie literatury i jej obiegu w próbach nobilitacji komiksu swoje źródła ma w zjawiskach, jakie pojawiły się w Stanach Zjednoczonych pod koniec lat 70. i związane były z wyłonieniem się terminu graphic novel, powieści graficznej. W wyniku kampanii Werthama i pojawienia się kodeksu komiksowego, obieg powieści obrazkowych w USA został ograniczony. Dzieła komiksowe publikowane były z myślą o młodzieży, co determinowało ich format i ceny. Wydawane były w kilkudziesięciostronicowych zeszytach a ich narracja była początkowo epizodyczna i opisywała perypetie konkretnego bohatera. W latach 6o. i na początku lat 70. zaczęto nadawać tym produkcjom charakter serializowany, a fabuła opowiadana zaczęła być rozwijana na przestrzeni kilku lub nawet kilkunastu zeszytów. Tego typu komiksy sprzedawane były najpierw w kioskach, a z czasem wykształciły się wyspecjalizowane sklepy, które - zrzeszając fanów komiksów - wytworzyły podwaliny pod rozwój zorganizowanej społeczności fanowskiej. Równolegle pod koniec lat 6o., pod wpływem niezgody na tematykę i ograniczenia sztuki komiksowej oficjalnego obiegu, wykształcił się komiks podziemny, związany z takimi twórcami jak Robert Crumb i Harvey Pekar ${ }^{69}$. Ich dzieła często opowiadały obrazoburcze historie, krytykując politykę, społeczeństwo i kulturę swych czasów. Dzieła te wciąż publikowane były w odcinkach, w drukowanych własnym kosztem zinach, jednak ich recepcja była odmienna od oficjalnego podejścia do komiksu. Sztuką tą zainteresowały się osoby, które nie były klientami sklepów z powieściami obrazkowymi. Zaistnienie tego obiegu skłoniło wydawców do szukania innych odbiorców i otwarcia się na nowe rynki. W 1978 roku wydano Umowę $z$ Bogiem Willa Eisnera ${ }^{70}$. To opowiadające o życiu nowojorskich Żydów dzieło skierowane było do dorosłych czytelników i opublikowano je w zwartym formacie książkowym z podtytułem "graphic novel". Taki sposób wydania nie tylko determinował treść, która mogła opowiadać spójną fabułę, niepodzieloną na odcinki, ale oznaczał również możliwość sprzedaży dzieła w księgarniach, wśród innych

68 Tamże, s. 88-96.

69 R. Sabin Comics, Comix and Graphic Novel. A History of Comics Art, Phaidon Press, Michigan 2001.

W. Eisner Umowa z Bogiem, przeł. J. Drewnowski, Egmont, Warszawa 2007. 
utworów literackich ${ }^{71}$. Otworzyło to dla komiksów nowy rynek, jednocześnie zbiegło się ze stopniowym odchodzeniem od kodeksu komiksowego i wydawaniem utworów o większych ambicjach artystycznych. Mimo że wiele uznanych przez pole produkcji kulturowej komiksów wychodziło najpierw w formie zserializowanej, jak Maus Arta Spiegelmana, na polu kulturowym wytworzyło się przeświadczenie, że powieść graficzna to nie tylko format wydawniczy, ale też dzieła o większej wartości, które mogą znaleźć się wyżej w hierarchii produkcji kulturowej ${ }^{72}$.

Przekonanie o rozróżnieniu na komiksy przynależące do kultury niskiej i dzieła o większych ambicjach, przez co zbliżone do pola literatury, zostało przeszczepione na grunt polski ${ }^{73}$. Miało wpływ na wygląd oferty poszczególnych wydawnictw, które podzieliły się na publikujące powieści graficzne i te skoncentrowane na dziełach komiksowych skierowanych do odbiorcy masowego. Nawet wydawnictwo Egmont, które pozornie wyłamuje się z tego podziału, w ofercie mając obydwie kategorie sztuki komiksowej, dla powieści graficznych stworzyło specjalną linie nazwaną „Mistrzowie Komiksu”, której celem jest przybliżenie czytelnikom „największych dzieł światowego komiksu [...], klasyków i wybitnych artystów"74. Przełamywanie dystynkcji między literaturą a sztuką komiksową najbardziej widoczne jest w przypadku wydawnictwa Centrala, którego założyciele wyjaśniają: „dla nas komiks oznacza pięknie wydaną, dobrze napisaną, wyjątkowo narysowaną literaturę"75.

Jeśli jednak przyjrzeć się publikowanym w Polsce komiksom skierowanym do masowego odbiorcy, zauważyć można, że formatem nie różnią się one od powieści graficznych. Są to również produkty kilkusetstronicowe, a jedynym odróżniającym wyznacznikiem masowości staje się projektowany przez autorów odbiorca i ich odcinkowość. Komiksy popularne często wydawane są w zbiorczych tomach, które jednak mimo tego podzielone są na odcinki.

71 F. Goldsmith The Readers'Advisory Guide to Graphic Novels, ALA Reader's Advisory, Washington 2010, s.32-47.

72 Tamże, s. 1-9.

73 J. Woynarowski Wstronę formy otwartej..., s. 9.

74 Komiksy tylko dla dorosłych, Egmont.pl/Komiksy/Komiksy-tylko-dla-doroslych,267293,k.html (lipiec 2017).

75 „For us, comics means beautifully published, well written, and exceptionally drawn literature" [tłum. własne], https://www.facebook.com/pg/Centrala/about/?ref=page_internal (lipiec 2017). 
Mechanizmy dystynkcji determinowane są więc głównie przez recepcję środowiskową i praktyki wydawnicze.

\section{6.}

Bourdieu ukazuje sztuki przynależne klasie średniej jako będące w ciągłym stanie nieokreślenia, zamknięte w mechanizmach deklasacji i reklasacji ${ }^{76}$. Dialektyka ta wydaje się trafną diagnozą polskiego środowiska fanów komiksów, którzy z jednej strony ironicznie mówią o gettyzacji i określają sztukę komiksową jako „bękarta kultury”"7, z drugiej zaś - budują na podstawie swojej niszowości i marginalizacji przekonanie o elitarności, konstruowane w przeświadczeniu o byciu w opozycji wobec mechanizmów dystrybucji kapitału. Równolegle jednak powstaje wiele koncepcji próbujących wykorzystać systemy redystrybucji dóbr kulturowych w celu zwiększenia wartości zarówno obiektu swojego zamiłowania, jak i swojej własnej, jako grupy społecznej.

Walka ta odbywa się na polach instytucji, obiegu kulturowego i akademii. Habitus fanowski opiera się na różnicowaniu siebie i przedmiotów, wokół których jest zogniskowany, od reszty pól, jednocześnie mając ambicje zniesienia tych różnic i wielokierunkowego zbliżenia się sztuk ${ }^{\mathbf{7 8}}$. Omawiane w tym artykule przykłady unaoczniają te zjawiska, jednocześnie ukazując środowisko komiksowe jako świadome społecznych mechanizmów konstruowania smaku. Szyłak stwierdza, że komiks odrzucany jest przez krytyków ze względu na traktowanie go jako czegoś „ułomnego" i „nieczystego" ${ }^{\text {"79. }}$. Można więc rozumieć opisywane zjawiska jako wielowektorową walkę o „oczyszczenie" na splecionych ze sobą polach estetycznych, społecznych i kulturowych.

\footnotetext{
76 P. Bourdieu Dystynkcja..., s. 209.

77 S. Frąckiewicz Komiks Bękartem Kultury...

78 P. Bourdieu Dystynkcja.., s. 218.

79 J.Szyłak Komiks w szponach miernoty, s. 161.
} 


\section{Abstract}

\section{Michał Jutkiewicz}

JAGIELLONIAN UNIVERSITY (CRACOW)

The Paradox of Distinction: The Comic Book on the Polish Cultural Marketplace

Jutkiewicz examines the state of Polish comic book art by drawing on Pierre Bourdieu's Distinction. In Poland, this art form was initially seen as part of low-brow culture, but when a tight-knit social group of fans emerged in the 1980s, attempts were made to enhance the status of the graphic novel. Jutkiewicz discusses a selection of those projects and their relationship to the mechanisms of distinction at play in the cultural marketplace.

\section{Keywords}

comic book, popular culture, cultural marketplace, cultural capital, distinction 